\title{
HUMANITY AND HAPPINESS - A VITAL FACTOR IN THE INDEPENDENT LIFE OF THE YOUNG GENERATION
}

\author{
Yuldashev Farrux Abdurakhmanovich \\ Fergana State University \\ Lecturer in the Department of Philosophy \\ Fergana. Uzbekistan
}

Article DOI: https://doi.org/10.36713/epra2170

\begin{abstract}
The role of humanism and national values are important in the contemporary policy of Uzbekistan. This study discusses the role and place of the ideas of humanism and tolerance in the development of ethics, culture, humanistic qualities of young people who are the leading forces of our society. The ideas on the wide use of the scientific heritage of the scientists and thinkers in the life of youth and nation have been considered. In the result of the study the factors of nurturing the young generation in promoting harmony and humanism have been drawn.
\end{abstract}

KEY WORDS: stability, independent thinking, personality, society, humanism, worldview, tolerance, progress, spiritual and moral maturity, interethnic harmony, compromise, dedication, diligence, thinker, spiritual legacy.

\section{INTRODUCTION}

Over the past twenty-eight years, reforms in all spheres have been aimed at ensuring peace, tranquility, social and spiritual life of our people, strengthening the respect for national values, love and devotion to the motherland, creating an atmosphere of tolerance in the young generation. Great attention is being paid to preserve the peace of the growing nations and citizens. Today it is important to strengthen the unity and harmony of nations and people around the world. When there is stability in the society, tolerance of nations is formed. The principle of tolerance, as one of the main ideas of our state ideology, plays an important role in uniting young people of different faiths and religions in our country for the sake of noble ideas and aspirations.

\section{IMPLEMENTING THE PEACEFUL POLICY INTO THE LIFE}

Attention is being paid to strengthen the tolerant environment in Uzbekistan. It is important to cite Shavkat Mirziyoyev, the President of the Republic of Uzbekistan: "We will focus on further developing the friendship and solidarity prevailing in our society, ensuring equal rights for all citizens, regardless of their nationality, religion or faith. The dissemination of extremist and radical ideas among them is absolutely forbidden in Uzbekistan"[1]. These qualities become a constant value for him when his personality, patriotism, dedication, diligence, and other personality traits coincide with the process of his personality formation. There is a need to instill in the hearts of young people knowledge and education, as well as national ideas. As a result of the peaceful policy pursued in our country, the achievement of stability and interethnic harmony in the society is achieved. On January 25, 2017, President of the Republic of Uzbekistan Shavkat Mirziyoyev signed a decree on awarding a group of activists of national cultural centers, who contributed to the development of our country, strengthening its tolerance, spiritual and humanitarian foundations to ensure the harmony. It is worth noting that our great thinkers have been bringing up our people in the spirit of humanism, peace, cooperation and solidarity with the ideas of religious tolerance, compromise, mutual respect and respect for people of different religions. Therefore, it is important to educate our young people in the spirit of the philosophy of humanism by feeding on the spiritual heritage of the great thinkers. The interethnic conflicts, bloody wars and various destructions that are taking place in the world today are the result of the destruction of the atmosphere of tolerance in society. It is necessary to prevent the catastrophe of tragedies, the spiritual life of many young people, the negative consequences of nationalism, religious separatism and neglect of other nations. In our basic law, such cases are strongly condemned, and the basic provisions concerning state and religious relations are in line with the legal norms of developed societies. Articles 18, 31, 61 of the Constitution and the provisions of the Law on Freedom of Conscience and 
Religious Organizations, providing for the right of every person to profess or not to profess any religion, prohibiting the compulsion of religious views, irrespective of their national, racial or religious origin and serve as a solid foundation for the promotion of harmony among the youth of our society [2,12-13]. In the multinational country, harmonization of interests of different nations and ensuring harmony among them is one of the important factors in shaping the thinking of national statehood. Today, in the course of large-scale reforms implemented by the head of our state to ensure human rights and interests, the principles of interethnic and interfaith harmony, solidarity and tolerance are further strengthened. The tolerance inherent in our people is for us one of the traditional national values, a solid foundation for maintaining national values in our homeland, creating the necessary conditions for the faith of all citizens, strengthening interethnic harmony and developing ancient common traditions. The tolerance inherent in our people is for us one of the traditional national values, a solid foundation for maintaining national values in our homeland, creating the necessary conditions for the faith of all citizens, strengthening interethnic harmony and developing ancient common traditions.

\section{NATIONAL INTERESTS IN THE DEVELOPMENT OF LIFE VALUES}

At the present stage it is important to pay attention to the balancing of the interests of nations in the development of society and the state, to consider the social status of the notions of stability and tolerance underlying interethnic relations. Sustainability is a concept that combines complex systemic aspects that are directly related to the concept of tolerance. This is because interethnic tolerance opens the door to interethnic relations to a whole new level and, thus, opens the way for their interrelationships and opportunities. At the same time, this notion is an objective process that deepens the dialectical relationship between national and universal values and serves the nation.

The key political document, the "Strategy of Action" is to radically improve the effectiveness of the reforms, create conditions for the comprehensive and accelerated development of the state and society, modernization of the country and liberalization of all spheres of life. It outlines the policy priorities in the field of interethnic relations [3-36-37]. It is important to note that in inter-ethnic relations, they share their common interests and their own values. In order to ensure the cohesion of the interests of nations in multinational countries, it is necessary to develop common values and criteria in society. It is desirable to create democratic legal criteria that protect the specific traditions, customs, values and interests of nations and create conditions for their development. The unity of national interests is an important factor in shaping the thinking of the national state, that every representative of a particular nation understands the uniqueness of his homeland, under the protection of a single state, and that national consciousness, formed in the minds of citizens, provides sustainable development.

\section{ENRICHMENT OF CULTURE THROUGH SCHOLARS' CONTRIBUTION}

It should be noted that the philosophical generalization of the moral factors of the formation of the youth as fully developed people, the development of important rules on youth problems and their elimination, and the importance of economic, political, social and spiritual factors in the formation of youth problems and their development in the country, should be kept. In other words, it is necessary to enrich the outlook of young people in ensuring high spirituality and moral perfection in society and youth activity, to strengthen their sense of devotion to the Motherland and values, to bring them up in the spirit of national and universal values. For this purpose, first of all, it is necessary to focus on the enrichment of the philosophical knowledge in the development of national outlook and thinking, the spiritual world, in the modernization of national spiritual and educational spheres, the analysis of the processes of globalization in the world.

Today, the development of society and the development of human culture are inseparably linked with the high level of knowledge, intellectual potential and enlightenment of the individual. In any society scholars and thinkers have played an immense role. It is worth noting that our great ancestors, rightfully proud of the achievements of our national culture, have a great respect for other cultures and strive to understand, learn and understand them. The interrelationship of all nations and peoples is related to culture. In the process of interaction in society, elements of other cultures are always drawn into one national culture. Such mutual enrichment, the process of emerging commonalities in them, is called internationalization.

History shows that such interaction and enrichment are accelerating in the development of society. Socio-economic and cultural ties play a major role in the emergence of international elements in culture. This indicates that internationalism represents a common aspect common to a number of national cultures. It is also important to determine what criteria are being used when assessing a particular event as international. Because some of the elements of the culture of the nation are one and the other may have something in common with the cultures of other nations. The development of science in Central Asia in the X-XII centuries was observed. The great thinkers have promoted the ideas of humanism and tolerance. 
One of our great thinkers, Ahmad al-Ferghani (approx. 798-865), was a prominent astronomer, mathematician, and geographer of the time, and wrote "The Basics of Astronomy," "Celestial Movements," and "Science about the Stars." Al-Khorezmi was one of the great philosophers of his time. He studied the principles of working with the human mind, dealing with the problems that people face with mathematics. The works of these scholars are being studied by scientists around the world.

Abu Nasr al-Farabi contributed to world science, culture and enlightenment. He has written over 160 works, some of which have been translated into Uzbek, Russian and other languages[4,235]. Abu Raihon Beruni works in the Khorezm Mamun Palace. He studied astronomy, physics, mathematics, geodesy, ore and other subjects. He has written 154 papers on astronomy, geography, mathematics and history. He first invented the globe. Abu Ali Ibn Sina (980 - 1037) studied logic, philosophy, mathematics and jurisprudence along with medical science. At the age of 16 he became a great referee and at 18 he became a great scholar of the East. His 35-year career is based on the attainment of perfection, knowledge and enlightenment as a result of human knowledge. The book Donishnama (Science Book) written by Ibni Sina in Persian (1031 or 1035) was not translated into any of the European languages until 1955. His work consists of three parts: Logics, Metaphysics, and Physics [5,101].

It is important to note that these thinkers, as encyclopedic scholars, have interpreted the cultures of the East and the West in their works. It is impossible to imagine the modern development of world scientific thinking without the works of our great ancestors, such as Khorezmian, Ferghani, Farabi, Beruni, Ibn Sina, the great contribution of the East to the development of world culture. Achievements in the development of world culture are found in every national culture. There are many examples of how East and West cultures have always been interconnected and enriched each other. Interaction of cultures, ideas about formation and development of tolerance in them, development of culture and education are closely connected with arts, religions and literature.

The events that occur within one culture may be absorbed into other cultures, transcended by their own national spirit, and thus re-acquired internationally. Some phenomena in national cultures, for example, science are international in its essence. After all, no matter what nationality the creators belong to, scientific truth is expressed in different languages, the conclusions, theorems, axioms, formulas of science are understandable to everyone. When it comes to national, international and universal elements in culture, one must pay attention to the methodological significance. The categories "nationality", "international" and "universal" constitute a dialectical association with each other, such as "singular", "private" and "general". Just as the categories of propriety and generality differ according to the degree of commonality, the categories of internationalism and humanity differ. Every culture is national in its essence, as its creator is a specific nation with its own history and way of life. Therefore, every culture, regardless of the number of its creators, is unique in its nature. But not every culture can ever be "pure" national. After all, culture of any nation has both national, international and universal elements. The events that we usually regard as national are also deeply humane in nature. For example, Oriental peoples' respect for hospitality, hospitality, love for children, and patience are all manifestations of human values in national colors. Such aspects are the ring that connects any culture with other peoples and with the entire human culture. From this point of view, it is important to further enhance the role of our scholars in the spiritual heritage, historical memory, and literary literature in the enhancement of knowledge and enlightenment, and in the absence of various manifestations in society. It is our duty to encourage young people to enrich their knowledge of our ancestors and to enhance their cultural and intellectual potential $[6,4]$.

In general, human culture, knowledge and enlightenment are the unity of national cultures that manifest themselves through international and universal symbols. In the development of cultures, the unity of nationalism and of humanity, as a holistic and multifaceted process, develops on the basis of universal social laws and is the result of the historical and cultural activities of various peoples in education and upbringing. That is why it is necessary to work towards establishing a new system of education and training.[7-131] It is precisely education and enlightenment that are key to the well-being of humanity, encouraging people to do good, and encouraging generous patience.[8] Enlightenment is the only and most powerful power to free the world, to bring it out of the swamp of ignorance and superstition, to solve its spiritual and economic problems.

\section{THE RESULTS OF THE STUDY}

In the result of the study of the above problems the following can be drawn, as the main factors in nurturing the young generation:

- Demonstrating the role of ethical, aesthetic, political, legal, and democratic factors in the education of young people in civil society;

- Increasing the role of spiritual values in furthering the intellectual potential of young people;

- In the process of spiritual renewal, we should pay more attention to the education of young people, as harmoniously developed individuals, to create a new ethical environment, a new type of quality; 
- Globalization and a vigilant attitude towards those young people;

-Wide promotion of scientific life of scientists and statesmen, scientific activity among young people.

\section{CONCLUSION}

In conclusion, in today's difficult situation, the issue of further strengthening friendship and solidarity among youth of different nationalities and religions in our country is of particular importance. The principle of humanity and tolerance in interethnic relations also contributes to respect for universal values and to ensuring global stability. The unity of the interests of nations is a matter of confidence, independence and the future of the nation, which will help strengthen the principles of tolerance and tolerance among the youth of our society, promote the ideas of interethnic solidarity, and promote social and spiritual development in society.

In the study of youth problems, first of all, the development of systematic, scientific and theoretical knowledge, the broad application of philosophical views, the identification, analysis, historical and logical, universal and national principles of the youth, the use of social and philosophical techniques such as unity have been considered. While writing the article a great deal of attention was paid to the issues of ethical relations, upbringing of the person, raising the consciousness of young people and their spiritual life.[9]

\section{REFERENCES}

1. "We will build a free and prosperous, democratic Uzbekistan with our brave and noble people" The people's word. December 15, 2016

2. The Constitution of the Republic of Uzbekistan "Uzbekistan", 2017

3. Decree of the President of the Republic of Uzbekistan on the Strategy of Action for the Further Development of the Republic of Uzbekistan. T. "Justice" 2017

4. B.Abduhalimov Scientific activity of scholars of "Bait al-Hikma" and Central Asia scientists in Baghdad. Tashkent.2010, p.235.

5. Haydarova G. Pardaeva K. Gapparova B. People's Pedagogy Tashkent 2009,p.101

6. Great thinkers of the great country Tashkent "Uzbekistan", p. 4

7. Qosimov B. "National Awakening" T, "Sharq", 2000, p.53

8. Imomnazarov $M$ "Basics of Spirituality". Tashkent. "East". 2001,p.131.

9. Mirziyoev Sh.M. Continuing our national development path to a new level Tashkent.Uzbekistan, 2018, p.28

10. Karimov I.A. High spirituality is an invincible force. Tashkent. "Spirituality", 2008, p.83 